\title{
„Niewiasta obleczona w słońce” (Ap 12,1) w interpretacji dominikanów XIII wieku
}

Księga Apokalipsy była poprzez wieki wielkim wyzwaniem dla biblijnych komentatorów i kaznodziejów. Analiza dawnych komentarzy tej księgi pozwoliła współczesnym autorom na sformułowanie twierdzenia, że rozdział dwunasty księgi był interpretowany w podwójnej perspektywie. Starożytność chrześcijańska upatrywała w postaci niewiasty obleczonej w słońce symbolu Kościoła, natomiast wieki średnie tłumaczyły ów fragment w perspektywie mariologicznej, upatrując w apokaliptycznej Niewieście postaci Matki Chrystusa ${ }^{1}$.

Olbrzymia liczba zachowanych średniowiecznych kazań wymogła zawężenie pola naszych poszukiwań do kazań wybranych dominikanów XIII stulecia. Z tego powodu przeanalizowano homilie na różne okoliczności roku liturgicznego: Sermones de tempore Peregryna z Opola ${ }^{2}$, kazania wielkopostne oraz Sermones de sanctis Jakuba z Voragine ${ }^{3}$, kazania maryjne Mikołaja z Mediolanu ${ }^{4}$ czy Bartłomieja z Breganze ${ }^{5}$. Wszystkie wywodzą się z tego samego środowiska religijnego (Ordo Praedicatorum). Powstały w tym samym czasie, jednakże były adresowane do różnych środowisk.

${ }^{1}$ P. Farkaš, La Donna di Apocalisse 12. Storia, bilancio, nuove prospettive, Roma 1997, s. $186-190$.

${ }^{2}$ Peregrinus de Opole, Sermones de tempore et de sanctis, ed. R. Tatarzyński, Warszawa 1987, s. $1-304$.

${ }^{3}$ Iacopo da Varazze, Sermones Quadragesimales, ed. G. P. Maggioni, Firenze 2005; tenże, Sermones de sanctis per anni totius circulum, Venetiis 1573.

${ }^{4}$ Nicola de Milano, Collationes de Beata Virgine, ed. M. M. Mulchahey, Toronto 1997.

${ }^{5}$ Bartolomeo da Breganze, I Sermones de Beata Virgine, ed. L. Gaffuri, Padova 1993. 
Celem niniejszej analizy jest prezentacja komentarzy Ap 12, 1 w homiliach wybranych dominikańskich kaznodziejów XIII wieku oraz dokonanie weryfikacji istniejących do tej pory interpretacji. W ostatnim stuleciu powstało wiele komentarzy egzegetycznych na temat Ap 12, 1, wśród których nie sposób nie wymienić prac: J. Ernsta ${ }^{6}, \mathrm{H}$. Cazellesa ${ }^{7}$, A. Feuilleta ${ }^{8}$, S. Lyonneta ${ }^{9}$, F. Montagniniego ${ }^{10}$, A. Valentiniego ${ }^{11}$, $\mathrm{U}$. Vanniego ${ }^{12}$. Pomimo zainteresowania badaczy wspomnianym tekstem prac na temat historii egzegezy Ap 12, 1 jest niewiele. Wielotomowa Bibliografia Mariana Giuseppe Besuttiego wymienia jedynie dwie pozycje: G. Lobrichona ${ }^{13}$ i L. Stefaniaka ${ }^{14}$, do których należy dodać ostatnio opublikowaną pracę zbiorową pod redakcją C. M. Piastry ${ }^{15}$. Ponieważ wymienione opracowania nie uwzględniają egzegezy dominikańskich kaznodziejów, dlatego też niniejsze opracowanie posiada charakter oryginalny, stanowi przyczynek, który uzupełnia istniejące do tej pory luki w literaturze tematu.

${ }^{6}$ J. Ernst, Die «himmlische Frau» im 12 Kapitel der Apokalypse, [w:] „Theologie und Glaube" 58 (1968), s. 39-58.

${ }^{7} \mathrm{H}$. Cazelles, Note d'exégèse sur Apocalypse 12, [w:] Mater Fidei et Fidelium. Collected Esseys to Honour Theodore Koehler on His 80th Birthday, Dayton 1985-1991, s. 131-134 (Marian Library Studies. New Series, 17-23).

${ }^{8}$ A. Feuillet, Le Messie et sa Mère d'après le chapitre XII de l'Apocalypse, „Revue Biblique” 66 (1959), s. 55-86.

${ }^{9}$ S. Lyonnet, Maria S.ma nell'Apocalisse, „Tabor” 26 (1959), s. 213-222.

${ }^{10} \mathrm{~J}$. Montagnini, Le «signe» d'Apocalypse 12 à la lumière de la christologie du Nouveau Testament, „Nuovelle Revue Théologique” 89 (1967), s. 401-416.

${ }^{11}$ A. Valentini, Il «Grande segno», „Theotokos” 8 (2000), s. 3-15.

${ }^{12}$ U. Vanni, La figura della donna in Apocalisse, „Studia Missionalia” 40 (1991), s. 57-94.

${ }^{13} \mathrm{G}$. Lobrichon, La femme d'Apocalypse 12 dans l'exégesè du haut moyen âge latin (760-1200), [w:] Marie. Le culte de la Vierge dans la société médiévale, études réunies par D. Iogna-Prat, E. Palazzo, D. Russo, Paris 1996, 407-439.

${ }^{14}$ L. Stefaniak, Mulier amicta sole (Ap 12, 1-17) w świetle współczesnej egzegezy biblijnej, „Ruch Biblijny i Liturgiczny” 9 (1956), s. 262-283; tenże, Interpretacja 12 rozdziału Apokalipsy św. Jana w świetle historii egzegezy, Poznań 1957.

${ }^{15}$ Maria, l'Apocalisse e il Medioevo. Atti del III Convegno mariologico della Fondazione Ezio Franceschini con la collaborazione della Biblioteca Palatina di Parma. Parma, 10-11 maggio 2002, a cura di C. M. Piastra, F. Santi, Firenze 2006. 


\section{Kazania dominikańskich kaznodziejów XIII wieku}

Badanie sposobu, w jaki dominikańscy kaznodzieje wyjaśniali tekst Ap 12, 1, domaga się krótkiej prezentacji zbiorów kazań będących przedmiotem analiz. Spośród wielu kolekcji wybrano kazania następujących kaznodziejów.

Jakub z Voragine Sermones quadragesimales oraz Sermones de sanctis

Współcześni historycy zgodnie twierdzą, że Jakub z Voragine po ukończeniu redagowania Złotej legendy około 1267 roku $^{16}$ rozpoczął prace nad zbiorem schematów do kazań ${ }^{17}$. W latach 1277-1281 powstały sermones de sanctis. Natomiast w latach 1285-1292 zredagował zbiór 97 sermones quadragesimales ${ }^{18}$. Intencją autora było wyposażenie kaznodziejów w materiały pomocne w przygotowywaniu kazań.

Peregryn z Opola Sermones de tempore et de sanctis

Peregryn z Opola napisał swoje Sermones de tempore et de sanctis w latach 1297-130419. Pierwsza część zbioru zawiera 64 kazania de tempore, natomiast druga część 55 homilii de sanctis, rozszerzonych o 9 kazań wydobytych z rękopisów polskich ${ }^{20}$. Kolekcja kazań była przeznaczona na użytek ludowych kaznodziejów.

\section{Bartłomiej z Breganze Sermones de Beata Virgine}

Kolekcja 127 sermones de Beata Virgine Bartłomieja z Breganze powstała w okresie pełnienia przez niego urzędu biskupiego w Vicenza ${ }^{21}$.

${ }^{16} \mathrm{~S}$. Bertini Guidetti, I Sermones di Iacopo da Varazze. Il potere delle immagini nel Duecento, Firenze 1998, s. 32.

${ }^{17}$ „Rogatus, ut post compilatas legendas sanctorum aliquam quoque de ipsis sanctis facerem compilationem" (T. Kaeppeli, Scriptores Ordinis Praedicatorum, t. 2, Romae 1975, 359, n. 2155); por. N. Bériou, Les sermones latins après 1200, [w:] The Sermon, directed by B. M. Kienzle, Turnhout 2000, s. 513.

${ }^{18}$ Iacopo da Varazze, Sermones Quadragesimales, a cura di G. P. Maggioni, Firenze 2005.

${ }^{19}$ A. Podsiad, Wstep edytorski, [w:] Peregrinus de Opole, Sermones de tempore et de sanctis, dz. cyt., s. X.

${ }^{20}$ Tamże, s. XXX.

${ }^{21}$ L. Gaffuri, Introduzione, [w:] Bartolomeo da Breganze, I Sermones de Beata Virgine, Padova 1993, s. XXXVIII. 
List dziękczynny papieża Klemensa IV z 22 czerwca 1266 roku za dedykowanie jemu kazań informuje, że czas powstania kazań należy upatrywać przed wymienioną datą. Kazania zostały przypisane do najważniejszych uroczystości: Narodzenia Pańskiego, Zwiastowania, Oczyszczenia i Wniebowzięcia NMP.

\section{Mikołaj z Mediolanu Collationes de Beata Virgine}

Collationes de Beata Virgine Mikołaja z Mediolanu zostały wygłoszone do członków Bractwa Najświętszej Maryi Panny w Imola, które gromadziło się w kościele dominikanów, aby wieczorem śpiewać laudy ku czci Najświętszej Maryi Panny ${ }^{22}$. Kolekcja dwudziestu czterech collationes powstała w okresie pomiędzy 1286 a 1287 rokiem $^{23}$. Należy podkreślić, że współczesna edycja M. Mulchahey uwzględnia również inne collationes dominikanina z Mediolanu wydobyte z manuskryptu zachowanego Biblioteca Nazionale Centrale we Florencji ${ }^{24}$.

\section{Nowy typ dominikańskich kazań}

Dominikańskie homilie reprezentują nowy typ kazań zwany sermo modernus ${ }^{25}$.Jak zauważa XIII-wieczny dominikanin Tomasz Waleys, stary sposób głoszenia polegał na komentowaniu poszczególnych wersetów Ewangelii przepisanej na konkretny dzień roku liturgicznego ${ }^{26}$. Natomiast nowy sposób głoszenia opierał się szczegółowym opracowaniu tematu, który stanowił werset z Pisma Świętego ${ }^{27}$. Znane są również wyjątki od tej zasady. Jak zauważa M. M. Mulchahey, temat mógł także pochodzić z innych źródeł: liturgii, ojców Kościoła, popularnych pieśni. Temat (thema) był najistotniejszą kwestią, jaką kaznodzieja musiał wybrać, układając kazanie ${ }^{28}$. Był on następnie dzielony na części. Dokonany podział

${ }^{22}$ M. M. Mulchahey, Introduction, [w:] Nicola da Milano, Collationes de Beata Virgine, dz. cyt., s. 9.

${ }^{23}$ Tamże, s. 15.

${ }^{24}$ Tamże, s. 12.

${ }^{25}$ M. M. Mulchahey, «First the Bow Is Bent in Study....» Dominican Education before 1350, Toronto 1998, s. 401.

${ }^{26}$ Tamże, s. 402.

${ }^{27}$ Tamże, s. 402.

${ }^{28}$ Tamże, s. 404. 
decydował o strukturze, jak i o zawartości kazania ${ }^{29}$. Ustaliwszy schemat kazania, kaznodzieja przechodził do rozwinięcia jego poszczególnych części (dilatatio) ${ }^{30}$. W procesie redagowania kazania nie tylko odwoływał się do fragmentów Pisma Świętego, lecz również posługiwał się narzędziami, które umożliwiały odpowiednie skomentowanie tematu homilii.

W rozwinięciu kazania pomagały między innymi listy pojęć biblijnych opatrzonych wielorakimi znaczeniami (sens wyrazowy, alegoryczny, moralny) ${ }^{31}$. Kaznodzieje często powoływali się na auctoritates zaczerpnięte z uznanych źródeł. Kolejnym uznanym narzędziem były etymologie ujawniające semantyczne bogactwo biblijnych określen' ${ }^{32}$. Często wykorzystywano w kazaniach przykłady (exempla) ${ }^{33}$, aby zachęcić wiernych do przemiany obyczajów, umocnić wiarę ${ }^{34}$.

\section{Interpretacja Pisma Świętego przez \\ XIII-wiecznych kaznodziejów}

Średniowieczni kaznodzieje dokonywali egzegezy Pisma Świętego, skupiając się na dwóch jego sensach: wyrazowym i duchowym. Aby dojść do poznania znaczenia duchowego tekstu, należało najpierw zrozumieć sens wyrazowy tekstu. Dlatego też zwracano uwagę na znaczenie poszczególnych słów ${ }^{35}$. Przywiązywano między innymi dużą wagę do znaczenia biblijnych imion, ponieważ uważano, że zawierały one ukryte przesłanie pozostawione przez autorów natchnionych ${ }^{36}$.

Dzięki zastosowanej typologii postacie biblijne ujawniały sens alegoryczny. W tej perspektywie postacie Starego Testamentu stawały się zapowiedziami postaci Nowego Testamentu ${ }^{37}$.

\footnotetext{
${ }^{29}$ Tamże, s. 405.

${ }^{30}$ Tamże, s. 407.

${ }^{31}$ Tamże, s. 410.

${ }^{32}$ Tamże, s. 411.

${ }^{33}$ Tamże, s. 409.

${ }^{34}$ Tamże, s. 415.

${ }^{35} \mathrm{G}$. Dahan, L'exégèse chrétienne de la Bible en Occident médiéval XIIe-XIVe siècle, Paris

${ }^{36}$ Tamże, s. 317.

${ }^{37}$ Tamże, s. 345.
} 1999, s. 308. 
Kazania średniowiecznych kaznodziejów ukazują, że dzięki wielorakiej interpretacji można było wydobyć wiele znaczeń samej biblijnej postaci. Na przykład w Sermones Peregryna z Opola postać Chrystusa została proroczo zapowiedziana przez Króla Aswerusa ${ }^{38}$, proroka Eliasza ${ }^{39}$, kapłana wchodzącego do Świętego Świętych ${ }^{40}$. Wielość symboli i starotestamentalnych figur, które były zapowiedziami postaci Nowego Przymierza, zależała od przesłania, jakie miało być zawarte w homilii. W tym kontekście pojawia się pytanie: w jaki sposób interpretowano postać Niewiasty obecnej w dwunastym rozdziale księgi Apokalipsy?

\section{Interpretacja Ap 12, 1 w kazaniach dominikanów XIII wieku}

Analiza dominikańskich homilii ukazała różnorodność biblijnej interpretacji. Fragment Apokalipsy był odczytywany w perspektywie eklezjalnej, maryjnej oraz w świetle biografii innych świętych Pańskich. Stwierdzenie to zmienia rozpowszechnioną do tej pory opinię na temat egzegezy Ap 12,1 w homiliach średniowiecznych kaznodziejów.

\section{Niewiasta obleczona w słońce jako symbol Kościoła}

Wśród analizowanych komentarzy Ap 12, 1 kazania Peregryna z Opola zawierają eklezjalną interpretację tekstu. Niewiasta obleczona w słońce jawi się jako symbol Kościoła oraz chrześcijaństwa. W kazaniu na święto św. Jadwigi pisze: „«Zostały dane niewieście dwa skrzydła orła, aby uleciała na miejsce pustynne» (Ap 12, 1, 14). Słowa te pisze Jan w Apokalipsie 12 o pewnej kobiecie, które oznaczają święty Kościół i święte chrześcijaństwo" ${ }^{41}$.

${ }^{38}$ Peregrinus de Opole, Sermo in Dominica secunda post Epiphaniam Domini, [w:] tenże, Sermones de tempore et de sanctis, dz. cyt., s. 52.

${ }^{39}$ Peregrinus de Opole, Sermo in festo Ressurrectionis Domini, [w:] tenże, Sermones de tempore et de sanctis, dz. cyt., s. 112.

${ }^{40}$ Peregrinus de Opole, Sermo in Dominica quarta post Pascha, [w:] tenże, Sermones de tempore et de sanctis, dz. cyt., s. 144.

${ }^{41}$ Peregrinus de Opole, Sermo in festo sanctae Hedvigis viduae, [w:] tenże, Sermones de tempore et de sanctis, dz. cyt., s. 619: „«Date sunt mulieri duae alae aquilae, ut volaret in desertum locum» (Ap 12,1,14). Verba ista scribit Ioannes in Apocalypsi 12 de quadam muliere, quae significant sanctam Ecclesiam et sanctam christianitatem". 
Niewiasta obleczona w słońce jako symbol innych świętych Pańskich

Kazania Peregryna z Opola zawierają interesującą interpretację, w której symbol Niewiasty obleczonej w słońce $($ Ap 12,1$)$ jest odnoszony do św. Katarzyny. Obraz Niewiasty obleczonej w słońce odniesiony do Katarzyny zostaje wyjaśniony następująco: „W tych słowach św. Jan ukazał stan, jaki posiadała św. Katarzyna, jaki dom, jakie odzienie". Charakteryzując jej stan, podkreślił dziewictwo jako idealny stan, który wyklucza grzeszność. Opisując jej dom, to znaczy niebo, Peregryn wskazał na jej życie ziemskie, które charakteryzowało się tym, iż św. Katarzyna żyła na ziemi, lecz umysłem była zanurzona w niebie ${ }^{42}$. Obraz Niewiasty obleczonej w słońce został wyjaśniony w swoisty sposób: oznacza pewność św. Katarzyny, że jako przyobleczona w słońce uniknie piekielnych mrozów. Natomiast dwanaście gwiazd na głowie Niewiasty zostało zinterpretowane jako dwanaście radości, jakie dusza Katarzyny doświadcza w niebie, wśród których pierwsząjest radość podczas wprowadzania jej przez aniołów do nieba ( $\operatorname{ad} 6)$.

Podobną egzegezę można znaleźć w kazaniu na święto św. Jadwigi. Miejsce pustynne, do którego ucieka Jadwiga, to niebo, które jest pustynią dla wszelkiego zła. Dwa skrzydła, na których wznosi się święta, to cnoty miłosierdzia i pobożnościi ${ }^{43}(\operatorname{ad} 4)$.

\footnotetext{
${ }^{42}$ Peregrinus de Opole, Sermo in festo sanctae Catharinae virginis, [w:] tenże, Sermones de tempore et de sanctis, dz. cyt., s. 552-553: „«Mulier in caelo amicta sole. Et luna sub pedibus eius, et in capite eius corona duodecim stellarum». In verbis istis ostendit sanctus Ioannes, qualem beata Catharina habuit statum, qualem domum, quales vestes et quale crinale. Si volumus scire, qualem habuit statum, dicit quod virginalem. Mulier - inquit - non a corruptione, sed a sexu femineo. Felix, quae istum statum prae ceteris elegit, quia melior est, qui modo est in sancta Christianitate. Est enim status peccatorum et hic est malus. Est status poenitentium et hic est bonus. Et est status omnino non peccantium et hic fuit optimus et talis fuit status beatae Catharinae. Si volumus scire domum eius, dicit quod caelum. Felix autem, quod habuit tale domum, licet enim corpore habitaverit in terra, tamen mente habitabat in caelo. Si volumus scire, quale habuit vestes, dicit: amicta erat sole et ideo iam secura est, quia frigus infernale non laedit eam. Si volumus scire, quale sit crinale, dicit, quod habuit coronam stellarum duodecim, id est duodecim gaudiorum, quae sunt in caelo, et istis modo est coronata, quia duodecim sunt gaudia sanctorum in morte. Primum est, quod animae eorum feruntur ab angelis in caelo".

${ }^{43}$ Peregninus de Opole, Sermo on festo sanctae Hedvigis viduae, [w:] tenże, Sermones de tempore et de sanctis, dz. cyt., s. 619: „«Date sunt mulieri duae alae aquilae, ut volaret in desertum locum» (Ap 12,1,14). Verba ista scribit Ioannes in Apocalypsi 12 de quadam
} 
Niewiasta obleczona w słońce jako symbol Najświętszej Maryi Panny

Najczęstszą interpretacją Ap 12, 1 pojawiającą się w homiliach dominikanów jest egzegeza maryjna. Mikołaj z Mediolanu wyjaśnił ów tekst w świetle prawdy o wniebowzięciu Maryi, która dzięki Chrystusowi została wprowadzona do nieba i wywyższona ponad wszystkich świętych ${ }^{44}$. Moment wniebowzięcia Maryi został połączony z Jej ukoronowaniem ${ }^{45}$. Kaznodzieja z Mediolanu zwrócił uwagę na pewne podobieństwo zachodzące pomiędzy tekstem Ap 12, 1 a innym pochodzącym ze Starego Testamentu: „Stoi królowa po twojej prawicy w złocistej szacie”(Ps 44, 10 ${ }^{46}$.

Odmienne wyjaśnienie Ap 12, 1 zawierają sermones quadragesimales Jakuba z Voragine. Niewiasta obleczona w słońce to uwielbione ciało Maryi, natomiast szata, jaką było ono odziane, odznaczała się bielą ze względu na Jej dziewictwo, była pozłacana ze względu na Jej męczeństwo oraz jaśniejąca ze względu na świętość Maryi ${ }^{47}$.

muliere, quae significat sanctam Ecclesiam ut sanctam christianitatem. Hoc sumus nos omnes, sed secundum specialem intellectum possunt exponi de beata Hedvige. Per hanc igitur mulierem intelligitur beata Hedvigis, quae hodie volat in desertum locum, id est in caelum, quod est desertum omni malo et hoc duabus alis, id est duabus virtutibus, quae habuit. Et istae duae virtutes sunt in omnibus mulieribus, quae suam naturam nuntiant, videlicet pietas misericordiae et devotione".

${ }^{44}$ Nicola da Milano, Collatio 11, [w:] tenże, Collationes de Beata Virgine, dz. cyt., s. 45: „Sic in convivio celi ostendit Dominus matri sue tamquam nobiliori locum suum, ut quietetur eius desiderium, quia locatum in suo loco quiescit sicut lapis proiectus non quietatur donec veniat ad imum. Ap 12,1,4: Date sunt mulieri ale due, etc. Et sic Christus preparavit sue castissime matri immortalitatis locum super omnes alios sanctos, ut congratulans ecclesia dicat Cristo: Ostendisti aurore etc.".

${ }^{45}$ Nicola da Milano, Collatio 44, [w:] tamże, Collationes de beata virgine, dz. cyt., s. 92: „Set pulcerima in eius assumptione, quando rex glorie coronavit eam, et ideo ostensum fuit Iohanni in Apoc $(12,1)$ quod signum magnum apparuit in celo, mulier amicta sole etc.".

${ }^{46}$ Nicola da Milano, Collatio 28, [w:] tenże, Collationes de beata virgine, dz. cyt., s. 63: „Si queratur de vestitu, respondetur quod est amicta sole. Et Ps 44, 10: «Astitit regina a dextris tuis in vestitu deaurato». Si queratur ubi debet residere, respondet Ap $(12,1)$. «Signum magnum apparuit (in coelo)» etc.".

${ }^{47}$ Jacopo da Voragine, Sermo 212 in festo Assumptionis, [w:] tenże, Sermones de sanctis per anni totius circulum, dz. cyt., s. 304: „Quarto fuit luminosa a parte exteriori, cum dicitur: Amicta sole, quod est immortali corpore". Jacopo de Voragine, Sermo 219 de Assumptione, [w:] tenże, Sermones de sanctis per annis totius circulum, dz. cyt., 319. „Ista autem est mulier quae volavit cum duabus alis, id est cum glorificatione corporis et animae". 
Kazania włoskiego dominikanina zwracają uwagę na jeszcze jeden szczegół zawarty w obrazie Niewiasty. Dwanaście gwiazd na Jej głowie oznacza 9 zastępów aniołów oraz trzy zastępy świętych: męczenników, wyznawców i dziewic. To oni, a nie Chrystus, koronują Maryję. Symbol księżyca odnosi się do Kościoła. Ponieważ znajduje się on pod stopami Maryi, oznacza to Jej opiekę nad Kościołem ${ }^{48}$.

Dominującą perspektywą w kazaniach Jakuba z Voragine jest wniebowzięcie Błogosławionej Dziewicy. Określenie „Mulier amicta sole” odnosi on do Maryi, która stoi po prawicy Syna, wstawiając się za grzesznikami. Wyrażenie „odziana w złoto” (amicta sole) wyjaśnia w świetle Bożej mądrości, która według Pisma Świętego jest prawdziwym złotem. Maryja była odziana Bożą mądrością od momentu wcielenia, ponieważ w Niej przez dziewięć miesięcy zamieszkiwał Jezus - Mądrość Boża. Kolejny element apokaliptycznego obrazu circumdata varietate wskazuje na mieszkańców nieba otaczających Maryję, to znaczy zastępy męczenników, aniołów, wyznawców i dziewic ${ }^{49}$.

${ }^{48}$ Jacopo da Voragine, Sabbato, sermo II, [w:] tenże, Sermones quadragesimales, dz. cyt., s. 186: „Tertio fuit secum quando exivit de mundo, quia ipsam totam gloriosam et luminosam fecit. Hec est enim illa mulier de qua dicitur Apoc XII: «Mulier amicta sole et luna sub pedibus eius, et in capite eius corona stellarum duodecim, et in utero habens etc.» Ipsa enim est luminosa a parte superiori, quia habet coronam duodecim stellarum in capite. Duodecim stelle sunt duodecim ordines, scilicet novem ordines angelorum et tres hominum, scilicet martyrum, confessorum et virginum. Isti omnes eam coronant quia eam exornant. Est etiam luminosa a parte inferiori, ideo dicitur: «Et luna sub pedibus eius». Per lunam significatur ecclesia quam sub pedibus habet quia eam sub protectione tenet. Est luminosa a parte exteriori, «quia est amicta sole», id est glorificato corpore. Est luminosa a parte interiori, «quia in utero habens», ipsa enim divinum splendorem in utero habuit et ideo tota luminosa remansit".

${ }^{49}$ Jacopo de Voragine, Sabbato, sermo II, [w:] tenże, Sermones quadragesimales, dz. cyt., s. 264: „Ista tria habet nostra advocata, sicut David in spiritu sancto previdens dixit: «Astitit regina a dextris tuis»; ecce quanta diligentia, non enim ad horam recedit, sed a dextris filii semper assistit et pro peccatoribus intercedit; «In vestitu deaurato», ecce quanta sapientia, per aurum enim in scirptura divina sapientia intelligitur. Alii sancti habuerunt aurum, id est sapientiam divinam, sed nullus vestitus fuit auro nisi beata virgo, ideo dicitur: «In vestitu deaurato». Tunc enim divina sapientia ipsam vestivit, quando novem mensibus in eius utero habitavit; hinc ergo colligendum est quanta sapientia cor illius respenduit, quando divina sapientia novem mensibus in eius utero habitavit. Ista est illa mulier de qua dicitur Apoc. XII: «Signum magnum apparuit in celo, mulier amicta sole», tunc enim sole amicta fuit, quando sol iustitiae in eam descendit. «Circumdata varietate», ecce quanta gratia coram rege et sua familia, in tantum est 
Podobną maryjną interpretację Ap 12, 1 można znaleźć w kazaniach pochodzących z kolekcji Sermones de sanctis. Niewiasta jest figurą Błogosławionej Dziewicy, dwanaście gwiazd na Jej głowie symbolizuje dziewięć zastępów anielskich oraz trzy zastępy świętych: męczenników, wyznawców i dziewic ${ }^{50}$. Natomiast korona z gwiazd dwunastu na głowie Maryi oznacza Jej wyniesienie ponad wszystkie zastępy aniołów i świętych. Księżyc znajdujący się pod stopami Niewiasty kojarzy się ze zmiennością ${ }^{51}$. Odczytany w takim kontekście oznacza panowanie Maryi nad wszelką przemijalnością. Taka interpretacja pozwoliła dominikaninowi na wydobycie w kazaniu wątku moralnego. W tym świetle Błogosławiona Dziewica jawi się jako wzór życia chrześcijańskiego. Ponieważ dobra tego świata mogą ofiarować szczęście przemijające, a Maryja nimi wzgardziła, wobec tego także chrześcijanie powinni je odrzucić. Aby uwiarygodnić swoje twierdzenie, kaznodzieja odwołał się do autorytetu Pisma Świętego: „Omnis locus quem calcaverit pes vester, vester erit" (Pwt 11, 24). Zatem jeżeli podepczemy stopami to, co przemijające, jeżeli nie będziemy emocjonalnie związani z tymi dobrami, to dopiero wówczas staną się one prawdziwie naszymi ${ }^{52}$.

Specyficzną egzegezą Ap 12,1 odznaczają się Sermones de Beata Virgine Bartomieja z Breganze. Włoski dominikanin odczytał ów tekst w kontekście zaśnięcia i wniebowzięcia Maryi. Symbol Niewiasty odnosiłby się nie tyle do uwielbionego ciała Maryi, lecz do osoby Błogosławionej Dziewicy, która po śmierci i zmartwychwstaniu została wzięta do nieba. W chwili zaśnięcia dusza Maryi została uwielbiona, a następnie po-

enim in tota curia celesti gratiosa quod omnes eam circumdant. Nam in celo quot sunt ordines tot sunt varietates et tamquam domicelli eam tamquam dominam et reginam semper associant et circumdant; ideo cantat ecclesia: «Sicut dies verni circumdabant eam flores rosarum», id est omnes societates martyrum, «et lilia convallium», id est omnes societates angelorum, confessorum et virginum".

${ }^{50}$ Jacopo de Voragine, Sermo CCXII de Assumptione, [w:] tenże, Sermones de sanctis per anni totius circulum, dz. cyt., s. 302.

${ }^{51}$ Jacopo de Voragine, Sermo CCXII, [w:] tenże, Sermones de sanctis per anni totius circulum, dz. cyt., s. 302: „Per lunam mutabilitas designatur”.

${ }^{52}$ Jacopo de Voragine, Sermo 212 de Assumptione, [w:] tenże, Sermones de sanctis per anni totius circulum, dz. cyt., s. 303: „Ista etiam lunam sub pedibus habuit, quia omnia terrena calcavit per paupertatem voluntariam quam elegit. Dicitur autem: Omnis locus quem calcaverit pes vester, vester erit. Si enim temporalia calcaremus sub pedibus, et ea non tangeremus affectibus, veraciter nostra essent". 
nownie zjednoczona z ciałem, aby cieszyć się chwałą nieba. Widziana w tej perspektywie Mulier amicta sole objawia właściwości uwielbionego ciała: jasność (claritas), subtelność (subtilitas), dynamizm (agilitas) oraz niepodleganie cierpieniom (impassibilitas) ${ }^{53}$.

Korona z gwiazd dwunastu na głowie Maryi odnosi się do dwunastu apostołów. Apostołowie jaśnieją dzięki uczestniczeniu w życiu nadprzyrodzonym. Reprezentują porządek Bożej łaski, a nie Prawa ${ }^{54}$.

Bartłomiej z Breganze wyjaśnił również apokaliptyczny fragment w kontekście tajemnicy wcielenia. Niewiasta obleczona w słońce to Błogosławiona Dziewica, która nosiła w swoim łonie Jezusa - Słońce sprawiedliwości ${ }^{55}$. Nie sposób nie zauważyć, że interesujący nas tekst został wykorzystany przez kaznodzieję dla zilustrowania prawdy o wstawienniczej roli Maryi w niebie. Księżyc znajdujący się pod stopami Niewiasty oznacza zaproszenie ludu Bożego do kontemplacji Maryi, a szczególnie Jej miłosierdzia ${ }^{56}$.

${ }^{53}$ Bartolomeo da Breganze, Sermo 5 in Nativitate, [w:] tenże, I Sermones de Beata Virgine, dz. cyt., s. 30: „Anima Marie post dormitionem suam glorificata unita est corpori et sicut forma et sicut materia, et tali corpori qualis erat anima ipsa, unde in Apocalypsi XI (I), significatur per mulierem amictam sole propter quatuor solis proprietates que fuerunt in corpore glorificato resumpto, claritas videlicet, subtilitas, agilitas et impassibilitas. Hec enim forma id est anima formosa post dormitionem corpori formoso unita inseparabiliter adheret ei et movet ipsum iocunde per celum, unde non habet locum in Virgine id quod ait Agag pinguissimus, 1 Rg XI $(15,32)$ : sic ne «separat amara mors»?".

${ }^{54}$ Bartolomeo da Breganze, Sermo 6 in Nativitate, [w:] tenże, I Sermones de Beata Virgine, dz. cyt., s. 40: „Set et viri signiferi duodecim apostoli multo clariores fuerunt sub gracia quam sub lege, significati per coronam duodecim stellarum quam Maria in capite habuit, Apoc XII (I), quia insignium apostolorum chorea que Christum circumdedit matrem ornavit".

${ }^{55}$ Bartolomeo da Breganze, Sermo 63 in Annuntiatione, [w:] tenże, I Sermones de Beata Virgine, dz. cyt., s. 430: „Maria post conceptum inductam se reperit quia Christus sol iusticie in ea clausus eam illuminans per omnia ipsius mentis penetralia respexit et gloria Domini plenum Sir XLII (16), fuit cor eius quia totum divinis splendoribus illuminatum, totum ipsius ardoribus inflammatum, unde per mulierem amictam sole que in celo apparuit Apoc XII (1), significatur".

${ }^{56}$ Bartolomeo da Breganze, Sermo 77 in Annuntiatione, [w:] tenże, I Sermones de Beata Virgine, dz. cyt., s. 510: „Nos stature pigmee sumus et ab arbore siccomori confugimus cum Zacheo. Et quia sub luna sumus, id est sub Ecclesia, et cum luna mutamur que sub pedibus est mulieris amicte sole, genua flectamus ad Patrem Domini nostri Iesu Christi ut det nobis conprehendere cum omnibus sanctis qui sunt in terris que sit longitudp, 
Najobszerniejszy komentarz Ap 12,1 zawiera sermo 78 De Annuntiatione. Bartłomiej, wyjaśniając określenie signum magnum, stwierdził, że odnosi się ono do osoby, która objawiła się, podkreśla jej jakość, ukazuje miejsce, w którym objawienie dokonało się, oraz podkreśla relację. Jak zaznacza dominikanin, Niewiastą, która objawiła się św. Janowi, była Błogosławiona Dziewica. O Jej wyjątkowych przymiotach świadczy szata, którą została okryta. Natomiast miejscem, w którym się objawiła, jest niebo ${ }^{57}$.

Charakteryzując miejsce objawienia, Bartłomiej przedstawił opis nieba, opierając się na rozpowszechnionej w owym czasie doktrynie o poczwórnym niebie. Jego zdaniem, Błogosławiona Dziewica osiągnęła niebo trynitarne (coelum Trinitatis). Objawiła się również wszystkim zastępom aniołów w niebie empirejskim. W niebie ruchomym (coelum mobilis) ukazała się na początku jako gwiazda zaranna, natomiast w niebie eterycznym (coelum ethereum) najpierw objawiła się filozofom, a następnie Magom, którym objawiła się gwiazda w formie dziewiczej ${ }^{58}$.

latitudo, sublimitas et profundum misericordie ipsius matris, cuius maternitas non minus in celis et in terra nominatur quam experitur".

${ }^{57}$ Bartolomeo da Breganze, Sermo 78 in Annuntiatione, [w:] tenże, I Sermones de Beata Virgine, dz. cyt., s. 513-514: „«Signum magnum apparuit in celo, mulier amicta sole et luna sub pedibus eius et in capite eius corona stellarum duodecim». Satis ad signi magnitudinem testimonium discipuli quem diligebat Iesus, qui non nisi veritati testimonium perhiberet, facit, quod magnum ipsum signum fuisse dicit. Magnitudo tamen ipsius signi ostenditur ex persona et qualitate persone que apparuit, et ex loco in (514) quo apparuit, et ex situ loci. Persona mulier fuit, cuius qualitas describitur ex amictu et ornatu. Locus in quo apparuit celum fuit. Situs vero quia inter solem et lunam, supra verticem habens solem et sub pedibus lunam".

${ }^{58}$ Tamże, s. 514 (ad 16): „Locus in quo hec mulier insignis visa est celum est quadruplex. Visa est namque ab eterno in celo Trinitatis quia in speculo et in archetipo omnium creaturarum ordine dignitatis prior resplenduit. Unde ab initio, in Proverbiis, ordinatam se dicit. Hec in celo empireo prior omnium apparuit angelis, quia dignior ipsis et preclarior revelata est eis, quia luci angelice puritatis comparata invenitur prior. Hec in celo mobili apparuit a constitutione mundi, per stellam matutinam significata que diem precedit. Hec in celo ethereo apparuit in figura ostensa primo philosophis, postea Magis quibus stella in virginea forma refulsit habens in gremio filium quem duplici spica lactabat et super filium crucis formam. Signi duplicis sensibilis apparencia et apparitio significavit quod Virgo sacra cogitatione et aviditate tota in celo fuit: reperta quidem est ab archangelo corpore in cubiculo set mente conversabatur in celo". 
Ponadto zauważył, że miejsce Niewiasty pomiędzy słońcem a księżycem zdaje się wskazywać, iż Błogosławiona Dziewica jest pośredniczką pomiędzy Chrystusem a Kościołem ${ }^{59}$.

Gwiaździstej koronie Maryi został przypisany sens moralny. Dwunastu gwiazdom odpowiada dwanaście darów i łask udzielonych Maryi. Są nimi: nobilitas generis, singularis custodia, fama et benedictio generalis, affectionis puritas, sinceritas racionis, plenitudo intellectus, pontus auctoritatis, humilitatis recursus. Płynąca z owych darów chwała obejmuje nie tylko Maryję, lecz również rozciąga się na Józefa, Jej męża, ponieważ, jak argumentuje Bartłomiej, mąż jest głową rodziny ${ }^{60}$

Bartłomiej opisuje każdy duchowy dar, jaki otrzymała Maryja. Pierwsza gwiazda wskazuje na Jej szlachetne pochodzenie. Ponieważ według genealogii Józef pochodził z rodu Dawida, dlatego również Maryja prawdopodobnie pochodziła z tego pokolenia ${ }^{61}$. Kolejną cnotą Matki Chrystusa była integralność Jej umysłu i ciała. Zdaniem kaznodziei Maryja była dziewicą nie tylko w umyśle oraz w ciele, lecz również przestrzegała złożonego w momencie zwiastowania ślubu czystości ${ }^{62}$.

Trzecia gwiazda symbolizuje naturalną łagodność. Dominikanin z Breganze, aby wykazać wspomnianą cechę charakteru, posłużył się

${ }^{59}$ Tamże, s. 514-515 (ad 17): „Huius mulieris in celo situs fuit inter solem et lunam, et sole quidem induta et ornata fuit, quia eam decore induit et duodecim stellarum coronam ornavit. Luna vero non tam fulcita fuit quam pia ostensa et figurata. Nec enim sub pedibus habebat lunam ut luna substentaretur, set ut ab ea ei proximior iuvaretur et ut ad ipsam recursus facilior haberetur. Nempe, sicut vellus inter rorem et aream, sic Maria inter Christum et Ecclesiam".

${ }^{60}$ Tamże, s. 515-516 (ad 21): „Corona hec prerogativa est duodecim donorum et graciarum qua Ioseph, caput Marie, coronatus fuit, quia gloria sponse tota sponsi fuit quia, sicut scriptum est, «mulier diligens corona est viro suo» Prov. XII (4), et ab Apostolo scribitur quod «mulier gloria est viri sui». Hec stelle de natura sanctificate Virginis omnium artificis sapientie manu formate fuisse videntur et in unam laudis virginalis impresse coronam. Hec duodecim stelle fuerunt: nobilitas generis, integritas nature, mansuetudo naturalis, maritalis titulus, placentia universalis, singularis custodia, fama et benedictio generalis, affectionis puritas, sinceritas racionis, plenitudo intellectus, pondus auctoritatis, humilitatis recursus".

${ }^{61}$ Tamże, s. 516 (ad 22): „Prima igitur stella fuit nobilitas generis, quia stella hec orta fuit de Iacob et posterioribus patriarchis et de domo et familia David. Etiam hec stella gloria fuit Ioseph, quia per ipsius genealogie descriptionem regius Marie ortus probatus fuit".

${ }^{62}$ Tamże, s. 516 (ad 23): „Secunda stella fuit integritas carnis et mentis, quia virgo fuit mente, virgo carne, virgo professione, unde ad virginem Gabriel missus dicitur". 
następującym rozumowaniem: o ile znana była łagodność królów Izraela, a jeszcze bardziej królów Judy, to łagodność matki królów przewyższa wszystkich pozostałych. Łagodność wynika również z prawdy o Bożym macierzyństwie. Syn Boży, który był łagodny, udzielił tego daru swojej Matce w momencie wcielenia ${ }^{63}$.

Kolejną cnotą Maryi była Jej czystość małżeńska ${ }^{64}$. Piąta z kolei gwiazda w koronie symbolizowała powszechną uprzejmość Matki Pana, która wyrażała się w wypowiadanych słowach, które wskazywały na Jej duchowe piękno ${ }^{65}$.

Maryja posiadała również szczególną ochronę. 0 ile bowiem pozostałe niewiasty były strzeżone przez matrony bądź przez eunuchów, o tyle stróżem Błogosławionej Dziewicy był anioł oraz Syn Boży ${ }^{66}$.

${ }^{63}$ Tamże, s. 516-517 (ad 24): „Tertia fuit mansuetudo naturalis, quia non solum de domo fuit qui plures filios habuit, set et de familia David, que per Salomonem regina ipsius prolem descendit. Reges autem Israel clementes erant, magis autem reges Iuda, et si reges, maxime regine. David autem omnium regum mitissimus fuit, velud tenerimus ligni vermiculus, quia, etsi zelo mordax, mitis tamen et humilis corde. Et mansuetudinis ipsius in formatione Virginis Dominus memor fuit, iuxta quod ipse propheta rogaverat : memento Domine David et omnis mansuetudinis eius, quia in ipsam Virginem naturaliter paternam mansuetudinem totam transfudit".

${ }^{64}$ Tamże, s. 517: „Quarta fuit titulus coniugalis et hec fuit gloria Ioseph qui talis et tante sponsus meruit reputari, cuius puritate sue virginitatis propositum foveretur, cuius fecunditate consimili Deo ipse Ioseph paterno nomine fungeretur, propter que ab Ysaia propheta dictum fuerat: "gaudebit sponsus super sponsam et gaudebit super te Dominus Deus tuus»".

${ }^{65}$ Tamże, s. 517 (ad 26): „Quinta fuit placentia universalis, quia Virgo placibilis fuit non solum facie set et voce, set et moribus, unde gracia plena dicitur, quia vox sua dulcis et facies plena est graciarum et nichil in eius moribus videre potes nisi choros virtutum. Hec placentia gloria Ioseph fuit, quia pulcritudo naturalis Virginis, a spirituali pulchritudine superinfusa et puritatis oculis quasi sepulta, in amorem pulchritudinis interioris animum Ioseph totum attraxit".

${ }^{66}$ Tamże, s. 517-518: „Sexta fuit custodia singularis. Virgines namque regie aliquando per matronas, aliquando per eunuchos custodiuntur. Hec vero custodita fuit per angelum qui eam stando servavit, qui viam eius in salutis (s. 518) prosperitate disposuit, qui salutarium suorum eundo et dedeundo pro Spiritu iter fecit. Nec solum per angelum sibi Mariam in sponsam custodivit Dei Filius, set, quasi non contentus, alio per semetipsum angelo attestante qui ait: «Dominus tecum, ut custodiat introitum et exitum tuum», introitum tui conceptus, exitum tui partus, et custodiat te in omni statu et tempore, in omni casu et loco ut pupilla oculi". 
Siódma korona oznaczała sławę oraz błogosławieństwo, o czym świadczą słowa pozdrowienia skierowane do Maryi: „błogosławiona jesteś między niewiastami” ${ }^{67}$. Maryja odznaczała się także czystością uczuć. Uczucie obecne w Jej duszy stało na straży pokory i czystości ${ }^{68}$. Dziewiąta gwiazda wskazywała prawość argumentów. Rozważając zachowanie Maryi podczas zwiastowania, Bartłomiej z Breganze stwierdził, że Jej zmieszanie było wyrazem rozwagi ${ }^{69}$.

Kolejną gwiazdą w koronie chwały była potęga intelektu oraz akceptacja argumentów opartych nie na przenikliwości argumentacji, lecz na wierze ${ }^{70}$. Należy dodać, że Jedenasta gwiazda wskazuje na powage autorytetu Maryi ${ }^{71}$. Natomiast ostatnia symbolizuje integralną pobożność Błogosławionej Dziewicy, która rozpłomienia miłosierdzie. Syn

${ }^{67}$ Tamże, s. 518: „Septima stella fuit fama et benedictio generalis, propter quam dictum fuit: «Benedicta tu in mulieribus». Sola enim fuit de qua nulla sinistra suspicio haberi potuit, sola tota famosa et ex omni parte laudabilis, et hec stella gloria Ioseph fuit laus sponse laus est sponsi".

${ }^{68}$ Tamże, s. 518: „Octava est puritas affectionis, scilicet affectio in Maria fuit ad custodiam humilitatis et castitatis talis et tanta quod, probato sermone sue laudis et fecundationis, propter suam nimiam puritatem auditu ipso turbata fuit".

${ }^{69}$ Tamże, s. 519: „Nona est sinceritas racionis. Etsi enim turbata fuit in sermone ipsius affectio non tamen racio, set serena permansit. Quod patet ex tenore cogitationis. Quia «cogitabat qualis esset ista salutatio», videbat quod in superficie laudem continebat et conceptum licet oculte promittebat. Set, quia per angelum sanctum a Deo missum fiebat et quia ispius testimonio Dominum secum habebat, quod non ex sua natura consequi debebat, aut gracie plenitudinem, aut inter mulieres singulariter benedictionem, virginalem silicet fecunditatem, videbat, et ideo racione serena «cogitabat qualis esset ista salutatio»".

${ }^{70}$ Tamże, s. 519: „Decima est amplitudo intellectus et comprehensio racionis que in Maria non a rationis ipsius perspicacia fuit, set a fide. Fides enim dedit ei latitudinem cordis qua cepit archanum super omnem sensum tante legationis, quod videlicet conciperet inviolata in utero et quod pareret illibata ex utero, quod ipsius cor caperet, quod esset et mater et virgo et quod in ea Deus homo. Hec amplitudo intellectus et comprehensio racionis per hoc quod quesivit : "Quomodo fiet istud?»".

${ }^{71}$ Tamże, s. 520: „Undecima est pondus auctoritatis et gravitas in puella senilis. Hec stella singulariter radiosa fuit, quia radios regie maiestatis testes multos produxit. Regalis namque auctoritatis et maiestatis est adventu potentis non cedere loco, non paveri aut aspectu aut occurso, blando et adulatorio turbari sermone, dubia examinare querendo et respondendo, uti pacis et hiis cum modestia et prudencia, «humiliari sub potenti Dei manu» et altiora quam promissa sint non postulare". 
Boży, który jest źródłem miłosierdzia, przyjąwszy ludzką naturę w łonie Dziewicy, sprawił, że stała się Ona Matką miłosierdzia ${ }^{72}$.

Miejsce zajmowane pomiędzy słońcem a księżycem ukazuje, że Wniebowzięta przewyższa wszystkich wiernych w Kościele pielgrzymującym, natomiast Chrystus (Słońce) przewyższa Błogosławioną Dziewicę. Maryja przewyższa także Kościół tryumfujący, to znaczy wszystkie zastępy aniołów, cherubinów i serafinów ${ }^{73}$.

W kolejnym kazaniu de Annuntiatione Bartłomiej, opierając się na Ap 12, 1, wyjaśnił funkcję pośrednictwa Maryi. Nawiązując do miejsca, jakie zajmuje Niewiasta pomiędzy słońcem a księżycem, stwierdził, że jest Ona pośredniczką pomiędzy Chrystusem a Kościołem ${ }^{74}$. Kaznodzieja podkreślił pośredniczącą rolę Maryi w Kościele.Jako Matka miłosierdzia spełnia pośredniczącą rolę wobec Chrystusa - Słońca sprawiedliwości, wstawiając się za ludem Bożym ${ }^{75}$. Uczestnicząc w niebieskiej chwale,

${ }^{72}$ Tamże, s. 521: „Ultima fuit pietas integralis que omnem integrat pietatem, que omnem accendit misericordiam. Nam super naturalem misericordiam Domini misericordia que in celo erat in uterum Virginis descendit et eam matrem misericordie fecit et misericodiam in pietatem convertit".

${ }^{73}$ Tamże, s. 522: „Ipsa, ut diximus, inter solem et lunam fuit, inter Christum et Ecclesiam quia, etsi Christum ut hominem aliquando intra se habuit, supra se tamen ut Dominum semper. Porro, Ecclesiam quasi lunam «sub pedibus» suis non ideo habere dicitur quod Ecclesia militans minor ea sit et sub ipsius posita potestate. Nam supragreditur beata Virgo creaturas omnes, ita ut Ecclesia ipsa triumphans sit «sub pedibus eius». Ipsam namque super omnes angelorum choros, super cherubim quoque et seraphyn exaltatam nephas est dubitare, set, si pedes eius affectus ipsius sunt quorum vestigia cordibus et corporibus imprimit miserorum, «luna sub pedibus» illis est, quia omnium necessitates amplissimo quodam miseratur affectu, nam et defectus omnis sub ea est, et quicquid fragilitatis seu corruptionis est excellentissima quadam sublimitate excedit, subveniendo tamen et affectus suo miseris misericors admiscendo".

${ }^{74}$ Bartolomeo da Breganze, Sermo 80 in Annuntiatione, [w:] tenże, s. 526: „Lux solis luce lune nobis est altior, set lux lune nobis vicinior et suavior. Idcirco vellus inter rorem et aream, mulierem amictam solem inter solem et lunam legimus collocatam, quia Mariam mediatricem statutam credimus et gaudemus inter Filium et Ecclesiam".

${ }^{75}$ Bartolomeo da Breganze, Sermo 103 in Annuntiatione, [w:] tenże, I Sermones de Beata Virgine, dz. cyt., s. 676: „Semen electorum et germen electorum «Verbum caro factum», quia, sicut «mulier amicta sole» ostensa est Iohanni media inter solem et lunam, et vellus medium fuit inter rorem et aream, sic Maria et Christus in Maria inter Deum et Ecclesiam". 
została ozdobiona przez Chrystusa szatą chwały (stola gloriae) oraz koroną piękności ${ }^{76}$.

\section{Zakończenie}

Dokonana analiza pozwoliła na sformułowanie następujących wniosków. Interpretacja Ap 12, 1 w kazaniach dominikańskich autorów XIII wieku jest bogatsza, niż do tej pory przypuszczano. Obok egzegezy w perspektywie eklezjalnej i maryjnej ukazuje się nowy sposób interpretacji: odniesienie postaci apokaliptycznej Niewiasty do świętych Pańskich. 0 takiej interpretacji figury apokaliptycznej Niewiasty milczą biblijne opracowania. Należy również podkreślić szeroki zakres znaczeniowy innych elementów wchodzących w skład analizowanego przez nas obrazu. Słońce i księżyc odczytane w świetle antytezy wieczność, czas i przemijalność, Chrystus i Kościół. Umiejscowiona w tej perspektywie Maryja została ukazana nie tylko w tajemnicy wniebowzięcia, lecz równieżjako pośredniczka wstawiająca się za ludem Bożym u boku swojego Syna. Szata, w którą została obleczona Niewiasta, objawia bądź to Jej chwalebne ciało, bądź to całą osobę Maryi (dusza i ciało) uczestniczącą w Bożej chwale. Natomiast korona z gwiazd dwunastu odnosi się nie tylko do zastępów aniołów i świętych otaczających Maryję, lecz także do duchowych cnót i darów charakteryzujących postać Matki Pana. Warto także zwrócić uwagę na wyjaśnienia obrazu Niewiasty obleczonej w słońce w świetle tajemnicy wcielenia. Dokonana analiza ujawnia szerokie spektrum interpretacji obrazu Ap 12, 1 zawarte w kazaniach dominikanów XIII wieku. Dobrze to świadczy o teologicznym przygotowaniu, jak i o warsztacie ówczesnych kaznodziejów.

Poznań

BOGUSEAW KOCHANIEWICZ OP

${ }^{76}$ Bartolomeo da Breganze, Sermo 112 in Purificatione, [w:] tenże, I Sermones de Beata Virgine, dz. cyt., s. 745-746: „Nempe, ut preostendimus, vellus est medium inter rorem et aream, mulier inter solem et lunam, mater inter Christum et Ecclesiam constituta. Iam te, mater misericodie, per ipsum tue sincere affectum, tuis iacens pedibus sponsa quasi provoluta luna mediatricem apud solem iusticie constitutam devotis supplicationibus interpelllat: ut in lumine tuo videbat lumen et solis graciam, tuo mereatur optentu et de tuis manibus que gestasti recipiat, quam adamavit et adornavit pre omnibus stola glorie induens et coronam pulcritudinis ponens in capite tuo". 


\section{Słowa kluczowe}

Apokalipsa, interpretacja, dominikanie, Średniowiecze, mariologia, kaznodziejstwo

\section{Summary}

The „Woman clothed with the sun” (Rev 12:1) in the interpretation of the thirteenth century Dominicans

The analysis of the Dominican writings of 13th century allowed to formulate the following conclusions. The interpretation of the text Rev $12: 1$ in the Dominican preaching is richer than previously thought. Apart from the ecclesiological and Marian perspectives they reveal a new way of interpretation: the symbol of the apocalyptic woman clothed with the sun is referred to the saints.

It is also necessary to point out a wide range of meanings attributed to the image, the object of our analysis. The symbols of sun and moon had been read in light of the antithesis of the passing of time and eternity or of the other antithetical parallel: Christ and the Church. Reflected in this perspective, Mary has been shown not only in the mystery of the Assumption, but also as a mediatrix interceding for the people of God at the side of his Son. The bright robe, with which was clothed the apocalyptic woman, revealed either glorious body of Mary, either her whole person (the soul and body), participating in God's glory. While the crown of twelve stars refers not only to the legions of angels and saints that surround Mary, but also to the spiritual virtues and the gifts that characterize the figure of Our Lady. Finally, it is necessary to add an unusual interpretation of the image of woman clothed with the sun in the light of the mystery of the Incarnation.

The analysis of the sermons allowed us to discover a wide spectrum of the interpretation of the text Rev 12:1 by the thirteenth century Dominicans. Their sermons are witnesses of excellent theological and practical preparation of the medieval preachers.

\section{Keywords}

Revelation, interpretation, Dominicans, Middle Age, Mariology, preaching 